\title{
Modulation Effects on Acute Orofacial Inflammatory Pain in Rats by Curcuma longa L., Curcuma aromatica Salisb., Zingiber officinale Rosc. Extracts
}

\author{
Hee-Jin Kim*, Ja-Hyung Choi*, Hye-Jin Kim ${ }^{* *}$, Hyun-Soe Yoon ${ }^{* *}$ and Min-Kyung Lee ${ }^{\dagger, * *}$ \\ Department of Biomedical Health Science, Dong-eui University, Busan 47340, Korea
}

Curcuma longa L. (C.L), Curcuma aromatica Salisb. (C.A) and Zingiber officinale Rosc. (Z.O) of Zingiberaceae plants which are well known as effects of natural anti-oxidant, anti-cancer and anti-inflammatory. We examined that the Zingiberaceae plants are involved in development and modulation of orofacial pain in rats. Male, 7- to 8-week-old, Sprague-Dawley rats weighing 240 280 g were used in this study. Experiments were performed using acute pain model that was caused by the injection of $5 \%$ formalin into the right vibrissa pad. The number of scratching or rubbing to the injection site was recorded for 9 consecutive 5-minute intervals following injection of formalin. The experimental groups were acute orofacial inflammatory pain; control group (formalin, $5 \%$ ), vehicle group (5\% formalin after sodium carboxymethyl cellulose), single administration group, single mixed administration group, repeated administration group. The experiments were performed various concentrations of Zingiberaceae plants extract. Therefore, oral administration of C.L, C.A, and Z.O (p.o., concentrations of $12.5,25 \mathrm{mg} / \mathrm{mL}$ ) in orofacial inflammatory pain model substantially decrease the nociceptive behavior in a concentration dependent manner. And it tended to decrease at low concentration (12.5 mg/ $\mathrm{mL}$ ) of single mixed and repeated administration more than single administration. This result means that Zingiberaceae plants extract affects the modulation of acute orofacial inflammatory pain. Thus, Zingiberaceae plants extract may be a potential therapeutic treatment for orofacial inflammatory pain.

Key Words: Curcuma longa L., Curcuma aromatica Salisb., Zingiber officinale Rosc., Inflammatory, Orofacial pain

\section{서 론}

천연물에 존재하는 폴리페놀화합물(polyphenolics)은 천 연 색소로서 자연계에 널리 존재하고 있으며 주로 액포 및 세포막에서 유리형, 에스테르형 또는 결합형으로 존재 한다(Lee et al., 2011). 폴리페놀(polyphenols)에 존재하는 다수의 히드록실기 $(-\mathrm{OH})$ 는 여러 화합물과 쉽게 결합하는 특성을 가지고 있어 항암, 항염 및 항산화 효과가 뛰어나
다(Kim et al., 2012). 이미 선진각국에서는 천연물 산업 (natural products industry)에 대한 관심이 높아 이 분야의 연구개발에 역점을 두고 각종 천연물의 제품화와 산업화 에 역량을 집중하고 있는 추세이다(Hwang and Park, 2015). 다년생 초본(草本)에 속하는 생강과(Zingiberaceae) 식물들 에는 생강, 강황, 울금이 있다. 그 중에서 생강(Zingiber officinale Roscoe)은 향신료로 세계적으로 널리 사용되고 있으며 색은 어두운 노란색부터 황색 또는 붉은색을 띠 고, 생강 특유의 자극적인 향은 주성분인 gingerol, shogaol,

Received: August 5, 2019 / Revised: September 10, 2019 / Accepted: September 16, 2019

* Graduate student, ${ }^{* *}$ Professor.

${ }^{\dagger}$ Corresponding author: Min-Kyung Lee. Department of Biomedical Health Science, Dong-eui University, 176 Eongwangno(gayadong san24), Busanjin-gu, Busan 47340, Korea.

Tel: +82-51-890-4238, Fax: +82-0505-182-6878, e-mail: lmk849@deu.ac.kr

(C)The Korean Society for Biomedical Laboratory Sciences. All rights reserved.

@ This is an Open Access article distributed under the terms of the Creative Commons Attribution Non-Commercial License (http://creativecommons.org/licenses/by-nc/3.0/) which permits unrestricted non-commercial use, distribution, and reproduction in any medium, provided the original work is properly cited. 
zingerone 등에 기인하며, 이 외에도 flavonoids, terpenoids 등 다양한 생리활성 화합물이 존재하는 것으로 보고되고 있다(Guon and Chung, 2016). 생강 추출물 중의 하나인 6gingerol은 cyclooxygenase-2 (COX-2) 활성을 효과적으로 억제한다고 밝혀졌으며 shogaol과 gingerol이 prostaglandin (PG) 및 leukotriene 합성 효소의 효과적인 억제제로 보 고되었다(Kim et al., 2008). 생강과 식물에 속하는 울금 (Curcuma longa L., turmeric)은 전통적으로 한약재, 향신료 및 식용으로 사용되어 왔다(Kim and Lee, 2014). 울금의 다 양한 효능으로는 간장의 해독 촉진과 담즙의 분비작용 및 이혈작용이 뛰어나다. 따라서 이담작용과 방향선 건위 약, 카타르성 황달약, 담석증, 급성 간염약 등 국내외에서 다양한 처방과 제약의 원료로 수요가 많으며, 최근 울금 의 생리활성 물질인 curcuminoids의 약리 효과가 알려지면 서 의학 분야를 중심으로 많은 연구가 활발히 이루어지고 있는 실정이다(Kim et al., 2011). Curcuminoids는 세 가지의 화합물로 구성되어 있는데 curcumin, demethoxycurcumin (DMC) 및 bisdemethoxycurcumin (BMC)이며 그 중에서도 황색 색소로써 각종 약리적 활성을 가지고 있는 curcumin 은 오래전부터 의학, 약학, 식품학 분야 등에서 효능이 입증되었으며, 다양한 연구가 보고되었다(Kim et al., 2017). 마지막으로, 생강과(Zingiberaceae)의 강황 속(Curcuma)으 로 분류되는 다년생 식물 강황은(Anandakumar et al., 2014) 여러 실험을 통한 연구에서 주요 성분인 curcumin의 동맥 경화 억제, 항염증 및 항암 효과, 항산화 효과, 항균 효과 등이 규명되었다(Yoon et al., 2006). 이처럼 생강과 식물에 속하는 울금, 강황, 생강의 약리적 활성은 이미 입증되었 으며, 다양한 분야에서 천연물에 관련된 연구가 활발하게 이루어지고 있다. 그러나 아직까지 생강과 식물들이 구강 안면 영역에서 염증성 통증의 조절과 관련된 연구가 전 무한 실정이므로 본 연구에서 안면부 염증성 통증 발생 과 울금, 강황, 생강 추출물의 통증 완화에 대한 효과를 알아보고자 한다.

두부, 안면 및 모든 구강 내 구조물의 경조직 및 연조 직과 관련된 구강안면 통증(orofacial pain)은 치아 질환을 비롯하여 측두하악 관절 장애(temporomandibular disorders, $\mathrm{TMD}$ )뿐만 아니라 삼차신경통 같은 신경병성 통증까지 다양한 질환들이 유사한 형태의 동통으로 발현되므로 진 단이 어렵다(Choi et al., 2006). 구강은 음식, 음료 및 공기 의 섭취를 가능하게 하는 생물학적 구조이므로 인체의 발달, 성장 및 유지를 지원하는데 필요한 가장 기본적인 요소라고 할 수 있다. 따라서 구강 내 염증 부위의 병변
은 항상 인체 건강에 해롭고 개인을 구성하는 세포의 모 든 생물학적 활동을 손상시킨다(Moritani et al., 2018). 이러 한 염증반응은 생체의 항상성을 유지하기 위한 매우 필 수적이며 유익한 반응이지만 염증반응 조절에 실패하여 과분비 된 염증 매개 물질은 세포나 조직의 괴사 및 기 능 장애를 일으키고 활성화된 면역세포의 생존을 계속 유지시켜 만성 염증반응의 원인이 된다(Yoon et al., 2015). 통증은 조직 손상, 염증 발생 등과 같은 통증을 발생시키 는 자극에 의해서 통증성 신경전달물질이 유리되고 신경 전달물질이 세포막의 수용기에 작용하여 흥분성 활동전위 를 발생한다(Bae et al., 2013). 이러한 염증반응이 안면부 에 발생되면 안면부 염증성 통증이 유발된다. 이러한 통 증의 조절에 주로 많이 사용되고 있는 비스테로이드성 소염진통제(Nonsteroidal anti-inflammatory drug; NSAIDs)는 화학적으로 이질적인 화합물 군이며, 진통(analgesics) 및 항염(anti-inflammatory), 해열(antipyretic) 작용을 공통된 특 징으로 가지고 있다. 그러나 NSAIDs는 다양한 부작용을 일으키는데 특히 위장관에 다양한 합병증을 일으킬 수 있 다. 무증상의 위 점막 손상이나 속 쓰림, 소화불량으로부 터 생명을 위협하는 위출혈이나 십이지장의 궤양과 관련 이 있어(Song and Ha, 2009), 사용 시 주의를 필요로 한다. 타 인체 질환 치료제의 경우에는 천연물의 소재로 한 신 약 및 의약품이 출시되어 임상 치료에 적용되고 있으나 구강 질환 및 치과 관련 질환 치료에 이용되고 있는 의 약품은 대부분이 합성 약제로 부작용이 증가하는 추세이 고, 치의학 분야에서는 이에 대한 연구가 미미하다(Lee et al., 2011).

따라서 본 연구에서는 포르말린으로 유도한 안면부 염 증성 통증을 실험 모델에게 적용하여 울금, 강황, 생강 추 출물의 주입에 의한 통증 행위 반응 조절 효과를 확인하 고자 하였다.

\section{재료 및 방법}

\section{실험재료}

실험동물은 7 8주 령의 Sprague-Dawley 계 수컷 흰쥐 $(220 \sim 260 \mathrm{~g})$ 를 효창 사이언스(대구)에서 공급받아 사용하 였다. $23 \sim 25^{\circ} \mathrm{C}$ 의 일정한 실내 온도와 12 시간 주/야 순환 주기하여 환경을 유지하였으며, 물고 사료는 자유로이 공 급하였다. 행동적인 억압 등에 의한 실험 전 스트레스를 가능한 최소화하였으며, 본 연구는 의식이 있는 동물의 실험에 관한 통증 연구 학회의 윤리적 규정을 준수하고 
동의대학교 동물윤리 위원회의 승인(R2018-012)을 얻은 후 수행하였다.

\section{시약제조}

울금(국산)과 강황(인도산) 분말은 (주)청운 유통에서 구입하였으며, 생강(국산) 분말은 (주)현대 식품에서 구입 하여 사용하였다. $5 \%$ 포르말린 주입군과 용매군(Vehicle [veh.], 5\% sodium carboxymethyl cellulose [CMC-Na]), 울금 추출물 투여군, 강황 추출물 투여군, 생강 추출물 투여군 으로 실험 그룹은 구분하였고 $5 \% \mathrm{CMC}-\mathrm{Na}$ 에 각각 희석 하여 사용하였다. 각 약물의 투여는 단회와 반복(1일 1회, 3 일간 매일 1회) 그리고 단회 혼합(울금, 강황, 생강) 투여 군으로 구분하였다.

\section{안면부 염증성 통증의 발현 및 울금, 강황, 생강 추출물 효과의 평가}

랫드용 oral zonde $(\varnothing 1.8(15$ gauge $) * 80 \mathrm{~mm})$ 를 이용하여 울금, 강황, 생강 추출물을 각각 $1 \mathrm{~mL}$ 의 용량으로 경구 투여하였고, 약물의 주입은 포르말린에 의한 통증 유도 30 분 전에 시행하였다. 실험동물을 통증 반응 평가 전에 실험용 플라스틱 통에서 30 분 이상 적응시켰으며, 포르말 린 반응은 이 연구에서 사용된 방법과 동일하게 수행하 였다(Park et al., 2011). 실험동물 $(n=6)$ 의 오른쪽 수염부 피 하로 인슐린 주사기( $0.25 \mathrm{~mm}(31$ gauge)*8 mm)를 이용하여 $5 \%$ 포르말린 $(50 \mu \mathrm{L})$ 을 주입하였으며 약물이 주입된 안면

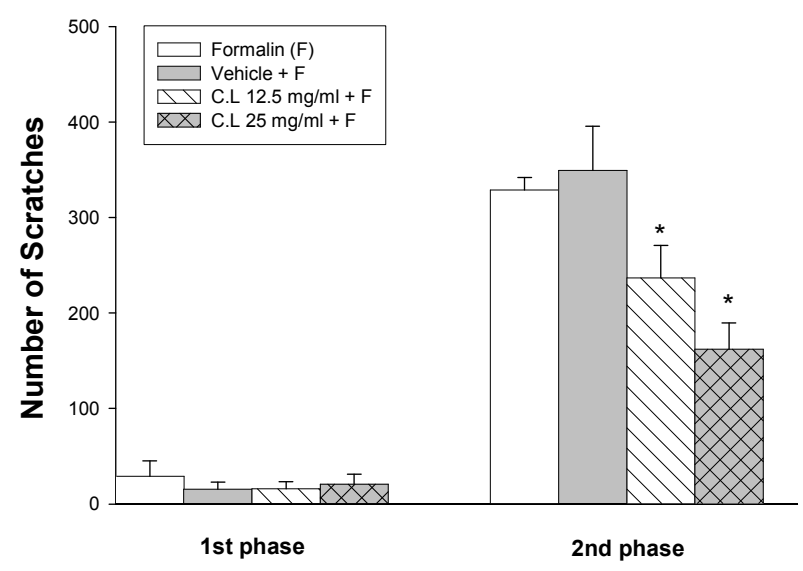

Fig. 1. Effects of C.L on nociceptive behavior at facial area. Following administration of C.L, the nociceptive responses were reduced in 2 nd phase in a dose-dependent manner. There were 6 animals in each group. $* P<0.05$, Formalin vs C.L $12.5,25 \mathrm{mg} / \mathrm{mL}$ $+\mathrm{F}$

C.L: Curcuma longa L.
부 부위를 문지르거나 긁는 행위를 통증 지표로 간주하 였다. 주입된 직후부터 5 분 단위로 누적하여 총 45 분간 기록하였으며, 1 차 반응(0 10분, 1 st phase)과 2차 반응(11 45분, 2nd phase)으로 구분하여 평가하였다.

\section{통계 분석}

실험 결과의 통계 분석은 IBM SPSS statistic ver. 22 (IBM Co., Armonk, NY, USA)을 사용하여 다중 그룹에서 반복 측 정 자료의 일원 배치 분산으로 분석하였으며 사후분석은 LSD post-hoc test를 이용하였다. 통계적인 비교를 위해 유 의수준은 $P<0.05$ 로 설정하였다. 결과는 평균 \pm 표준 오차 $(\mathrm{SEM})$ 로 표시하였다.

\section{결 과}

안면부 염증성 통증 행위 반응 조절에 울금 추출물의 효과

실험동물의 오른쪽 수염부 피하로 $5 \%$ 포르말린 $(50 \mu \mathrm{L})$ 을 투여하여 유도한 안면부 염증성 통증에서 울금의 통 증 행위 반응 조절 효과는 다음과 같이 나타났다(Fig. 1). 안면부 부위의 1 차 통증 행위 반응은 포르말린군과 용매 $(\mathrm{CMC}-\mathrm{Na})$ 군에서 각 $29.00 \pm 16.20,15.67 \pm 7.08$ 회로 나 타났고, 울금 투여군에서는 농도 $(12.5,25 \mathrm{mg} / \mathrm{mL})$ 에 따라

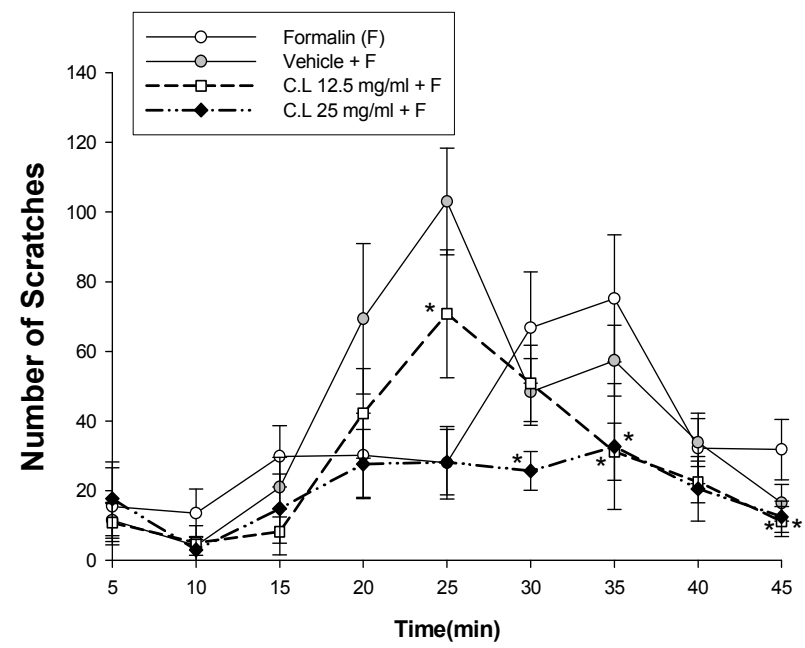

Fig. 2. Changes in nociceptive responses at facial area following administration of C.L. Oral administration of C.L, significantly reduced the nociceptive responses $20 \sim 30 \mathrm{mim}$ after induction of pain. There were 6 animals in each group. $* P<0.05$, Formalin vs C.L $12.5,25 \mathrm{mg} / \mathrm{mL}+\mathrm{F}$.

C.L: Curcuma longa L. 


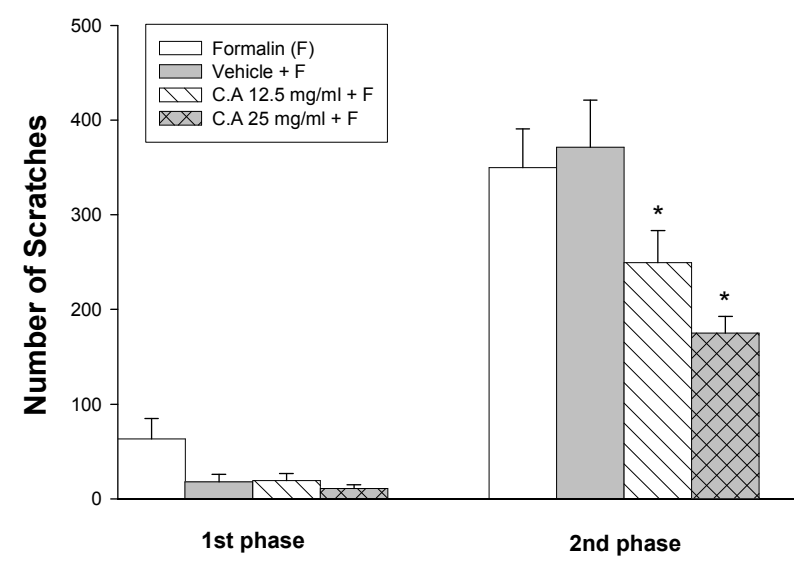

Fig. 3. Effects of C.A on nociceptive behavior at facial area. Following administration of C.A, the nociceptive responses were reduced in 2 nd phase in a dose-dependent manner. There were 6 animals in each group. ${ }^{*} P<0.05$, Formalin vs C.A $12.5,25 \mathrm{mg} / \mathrm{mL}$ $+\mathrm{F}$.

C.A: Curcuma aroma tica Salisb.

각 $15.83 \pm 7.42,20.67 \pm 10.46$ 회로 나타나 대조군과 실 험군 간의 차이가 없었다. 통증행위 2 차 반응의 결과에서 는 포르말린군과 용매군은 각 $329.00 \pm 12.86,349.33 \pm$ 46.15회로 통증 행위 반응이 높게 나타났으며, $12.5 \mathrm{mg} / \mathrm{mL}$ 의 울금 투여군은 $236.83 \pm 33.92$ 회로 대조군과 비교하여 통증 행위 반응이 감소됨을 나타났다. $25 \mathrm{mg} / \mathrm{mL}$ 의 농도에 서는 $162.00 \pm 27.68$ 회로 나타내어 대조군 및 $12.5 \mathrm{mg} / \mathrm{mL}$ 의 농도와 비교 시 통증 행위 반응이 농도 의존적으로 감 소됨을 확인하였다 $(P<0.05)$.

시간의 경과에 따른 통증 행위 반응의 변화는 다음과 같다(Fig. 2). 포르말린 주입으로 유도된 통증 행위 반응은 15 분 이후부터 증가하여 25 분에 가장 높게 나타났으며 40 분까지 통증이 지속되다가 45 분에 감소하였다. $12.5 \mathrm{mg} /$ $\mathrm{mL}$ 의 울금의 경구 투여는 포르말린 주입 후 30 35분, $25 \mathrm{mg} / \mathrm{mL}$ 는 20 30분에 포르말린에 의해 유도된 통증 행 위 반응을 유의하게 감소시켰다.

\section{안면부 염증성 통증 행위 반응 조절에 강황 추출물의 효과}

실험동물의 오른쪽 수염부 피하로 $5 \%$ 포르말린 $(50 \mu \mathrm{L})$ 을 투여하여 유도한 안면부 염증성 통증에서 강황의 통 증 행위 반응 조절 효과는 다음과 같이 나타났다(Fig. 3). 안면부 부위의 1 차 통증 행위 반응은 포르말린군과 용매 $(\mathrm{CMC}-\mathrm{Na})$ 군에서 각 $63.33 \pm 21.30,17.60 \pm 8.35$ 회로 나 타났고, 강황 투여군에서는 농도 $(12.5,25 \mathrm{mg} / \mathrm{mL})$ 에 따라

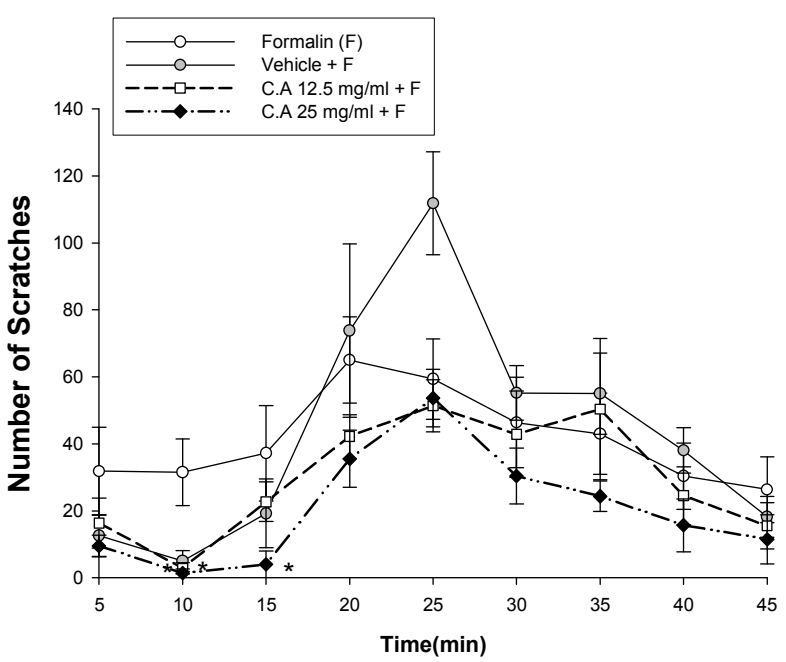

Fig. 4. Changes in nociceptive responses at facial area following administration of C.A. Oral administration of C.A, significantly reduced the nociceptive responses $20 \sim 30 \mathrm{mim}$ after induction of pain. There were 6 animals in each group. $* P<0.05$, Formalin vs C.A $12.5,25 \mathrm{mg} / \mathrm{mL}+\mathrm{F}$.

C.A: Curcuma aroma tica Salisb.

각 $19.17 \pm 7.31,10.83 \pm 3.88$ 회로 나타나 대조군과 실험 군 간의 차이가 없었다. 통증 행위 2 차 반응의 결과에서 는 포르말린 군과 용매군은 각 $350.10 \pm 40.54,371.20 \pm$ 49.78회로 통증 행위 반응이 높게 나타났으며, $12.5 \mathrm{mg} / \mathrm{mL}$ 의 강황 투여군은 $249.33 \pm 34.08$ 회로 대조군과 비교하여 통증 행위 반응이 감소됨을 나타냈다. $25 \mathrm{mg} / \mathrm{mL}$ 의 농도에 서는 $175.00 \pm 17.45$ 으로 나타내어 대조군 및 $12.5 \mathrm{mg} / \mathrm{mL}$ 의 농도와 비교 시 통증 행위 반응이 농도 의존적으로 감 소됨을 확인하였다 $(P<0.05)$.

시간의 경과에 따른 통증 행위 반응의 변화는 다음과 같다(Fig. 4). 포르말린의 주입으로 유도된 통증 행위 반응 은 15 분 이후부터 증가하여 25 분에 가장 높게 나타났으며 40 분까지 통증이 지속되다가 45 분에 감소하였다. $12.5 \mathrm{mg} /$ $\mathrm{mL}$ 의 강황의 경구 투여는 포르말린 주입 후 25 35분, $25 \mathrm{mg} / \mathrm{mL}$ 는 20 30분에 포르말린에 의해 유도된 통증 행 위 반응을 유의하게 감소시켰다.

\section{안면부 염증성 통증 행위 반응 조절에 생강 추출물의 효과}

실험동물의 오른쪽 수염부 피하로 $5 \%$ 포르말린 $(50 \mu \mathrm{L})$ 을 투여하여 유도한 안면부 염증성 통증에서 생강의 통 증 행위 반응 조절 효과는 다음과 같이 나타났다(Fig. 5). 안면부 부위의 1 차 통증 행위 반응은 포르말린군과 용매 


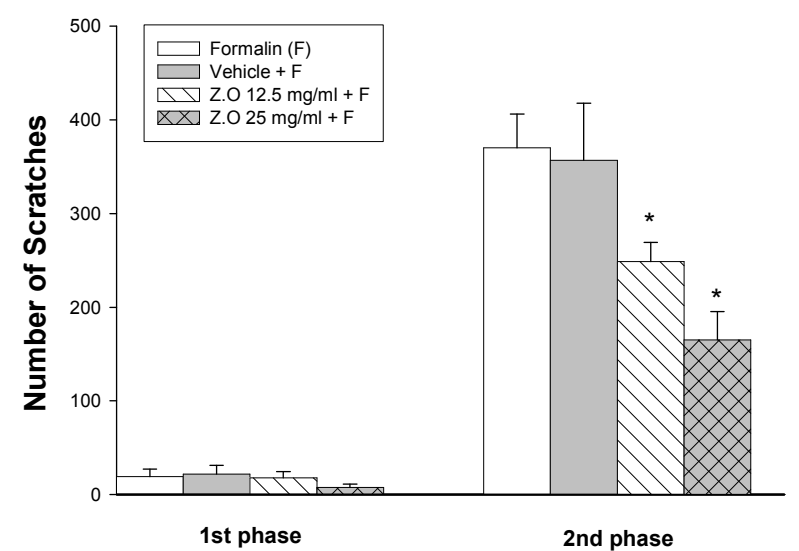

Fig. 5. Effects of Z.O on nociceptive behavior at facial area. Following administration of Z.O, the nociceptive responses were reduced in 2 nd phase in a dose-dependent manner. There were 6 animals in each group. ${ }^{*} P<0.05$, Formalin vs Z.O $12.5,25 \mathrm{mg} / \mathrm{mL}$ $+\mathrm{F}$

Z.O: Zingiber officinale Rosc.

(CMC-Na)군에서 각 $19.17 \pm 8.01,22.00 \pm$ 9.16회로 나타 났고, 생강 투여군에서는 농도 $(12.5,25 \mathrm{mg} / \mathrm{mL})$ 에 따라 각 $17.83 \pm 6.49,7.67 \pm 3.27$ 회로 나타나 대조군과 실험 군 간의 차이가 없었다. 통증 행위 2 차 반응의 결과에서 는 포르말린군과 용매군은 각 $370.00 \pm 35.94,357.00 \pm$ 60.63 회로 통증 행위 반응이 높게 나타났으며, $12.5 \mathrm{mg} / \mathrm{mL}$ 의 강황 투여군은 $248.50 \pm 20.78$ 회로 대조군과 비교하여 통증 행위 반응이 감소됨을 나타냈다. $25 \mathrm{mg} / \mathrm{mL}$ 의 농도에 서는 $165.00 \pm 30.07$ 회로 나타내어 대조군 및 $12.5 \mathrm{mg} /$ $\mathrm{mL}$ 의 농도와 비교 시 통증 행위 반응이 농도 의존적으로 감소됨을 확인하였다 $(P<0.05)$.

시간의 경과에 따른 통증 행위 반응의 변화는 다음과 같다(Fig. 6). 포르말린의 주입으로 유도된 통증 행위 반응 은 15 분 이후부터 증가하여 25 분에 가장 높게 나타났으며 40 분까지 통증이 지속되다가 45 분에 감소하였다. $12.5 \mathrm{mg} /$ $\mathrm{mL}$ 의 생강의 경구 투여는 포르말린 주입 후 30 35분, $25 \mathrm{mg} / \mathrm{mL}$ 는 20 30분에 포르말린에 의해 유도된 통증 행 위 반응을 유의하게 감소시켰다.

\section{안면부 염증성 통증 행위 반응 조절에 울금, 강황, 생강 추출물 혼합 투여의 효과}

실험동물의 오른쪽 수염부 피하로 $5 \%$ 포르말린 $(50 \mu \mathrm{L})$ 을 투여하여 유도한 안면부 염증성 통증에서 울금, 강황, 생강 단회 혼합 투여의 통증 행위 반응 조절 효과는 다 음과 같이 나타났다(Fig. 7). 안면부 부위의 1 차 통증 행위

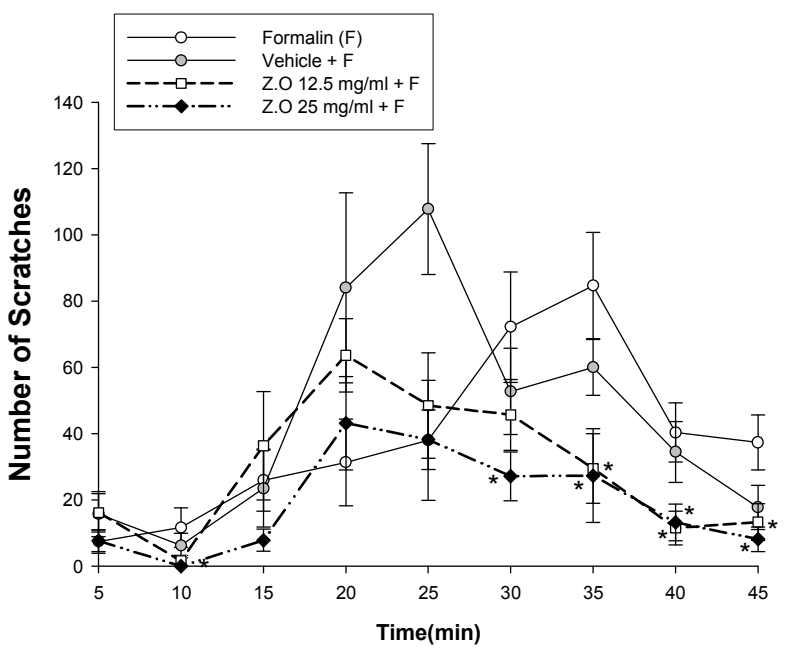

Fig. 6. Changes in nociceptive responses at facial area following administration of Z.O. Oral administration of Z.O, significantly reduced the nociceptive responses $20 \sim 30 \mathrm{mim}$ after induction of pain. There were 6 animals in each group. $* P<0.05$, Formalin vs Z.O $12.5,25 \mathrm{mg} / \mathrm{mL}+\mathrm{F}$.

Z.O: Zingiber officinale Rosc.

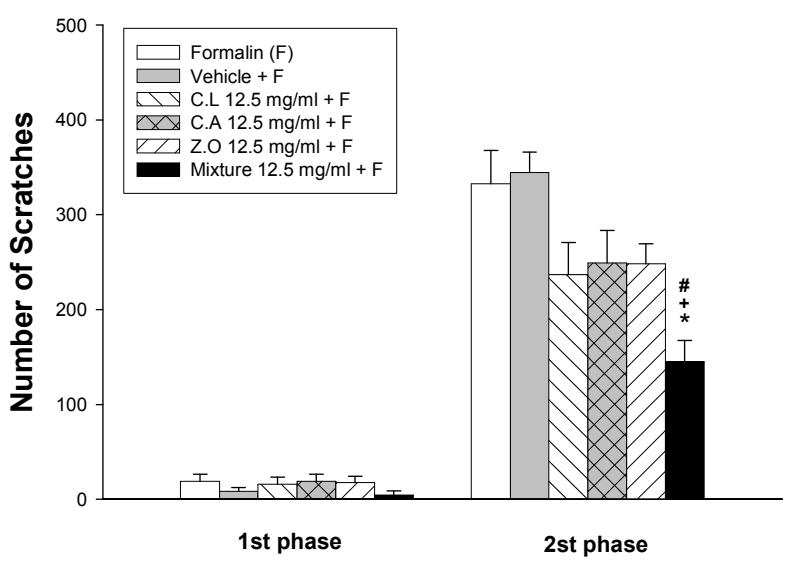

Fig. 7. Effects of mixture on nociceptive behavior at facial area. Following administration of mixture, the nociceptive responses were reduced in 2 nd phase in a dose-dependent manner. There were 6 animals in each group. ${ }^{*},+, \# P<0.05$, C.L, C.A, Z.O vs mixture $12.5 \mathrm{mg} / \mathrm{mL}+\mathrm{F}$.

*C.L: Curcuma longa L., +C.A: Curcuma aroma tica Salisb., \#Z.O: Zingiber officinale Rosc., Mixture: combine of C.L, C.A, Z.O

반응은 포르말린군과 용매(CMC-Na)군에서 각 $19.12 \pm$ $7.29,8.67 \pm 3.67$ 회로 나타났고, 울금, 강황, 생강 $12.5 \mathrm{mg} /$ $\mathrm{mL}$ 투여군에서는 각 $15.83 \pm 7.42,19.17 \pm 7.31,17.83 \pm$ 6.49 회로 나타났다. 울금, 강황, 생강 $12.5 \mathrm{mg} / \mathrm{mL}$ 을 혼합 하여 투여한 군에서는 $9.33 \pm 6.10$ 회로 나타나 대조군 


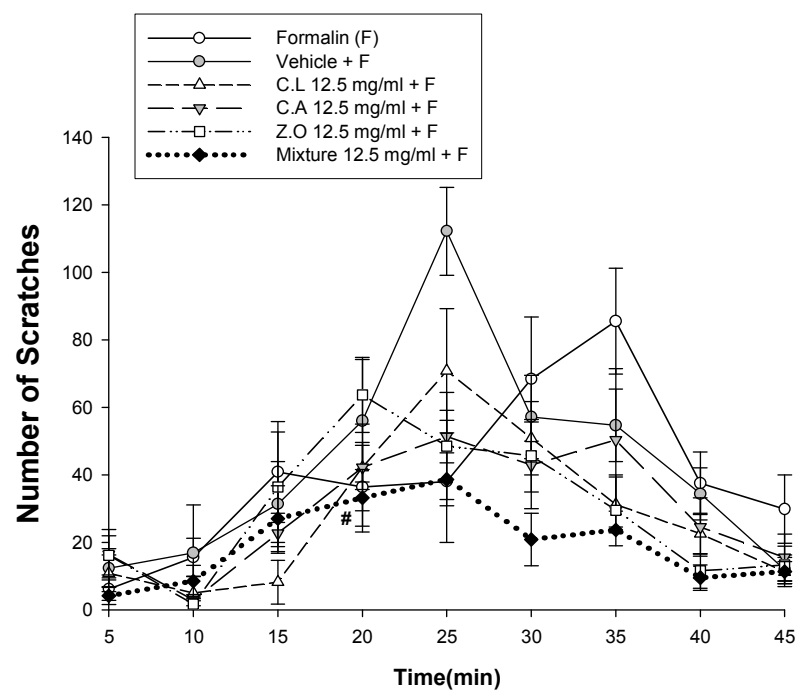

Fig. 8. Changes in nociceptive responses at facial area following administration of mixture. Oral administration of mixture, significantly reduced the nociceptive responses $20 \sim 30 \mathrm{mim}$ after induction of pain. There were 6 animals in each group. $\# P<0.05$, Z.O vs mixture $12.5 \mathrm{mg} / \mathrm{mL}+\mathrm{F}$

C.L: Curcuma longa L., C.A: Curcuma aroma tica Salisb., Z.O: Zingiber officinale Rosc., Mixture: combine of C.L, C.A, Z.O

과 실험군 간의 큰 차이가 없었다. 통증 행위 2 차 반응의 결과에서는 포르말린군과 용매군은 각 $332.67 \pm 35.11$, $344.50 \pm 21.43$ 회로 통증 행위 반응이 높게 나타났으며, $12.5 \mathrm{mg} / \mathrm{mL}$ 의 울금, 강황, 생강 투여군은 각 $236.83 \pm$ $33.93,249.33 \pm 34.08,248.50 \pm 20.78$ 회로 나타나 대조군 과 비교하여 통증 행위 반응이 감소됨을 나타냈다. 또한 이들과 비교하여 혼합 투여군에서는 $164.17 \pm 26.32$ 회로 나타나 대조군 및 울금, 강황, 생강 $12.5 \mathrm{mg} / \mathrm{mL}$ 와 비교 시 혼합 투여군에서 통증 행위 반응이 유의하게 감소됨을 확인하였다 $(P<0.05)$.

시간의 경과에 따른 통증 행위 반응의 변화는 다음과 같다(Fig. 8). 포르말린의 주입으로 유도된 통증 행위 반응 은 15 분 이후부터 증가하여 25 분에 가장 높게 나타났으며 40 분까지 통증이 지속되다가 45 분에 감소하였다. $12.5 \mathrm{mg} /$ $\mathrm{mL}$ 의 울금, 강황, 생강의 경구 투여는 포르말린 주입 후 20 35분, 혼합 투여군에서는 20 30분에 포르말린으로 유 도된 통증 행위 반응을 유의하게 감소시켰다.

안면부 염증성 통증 행위 반응 조절에 울금, 강황, 생강 추출물 반복 투여의 효과

실험동물의 오른쪽 수염부 피하로 $5 \%$ 포르말린 $(50 \mu \mathrm{L})$

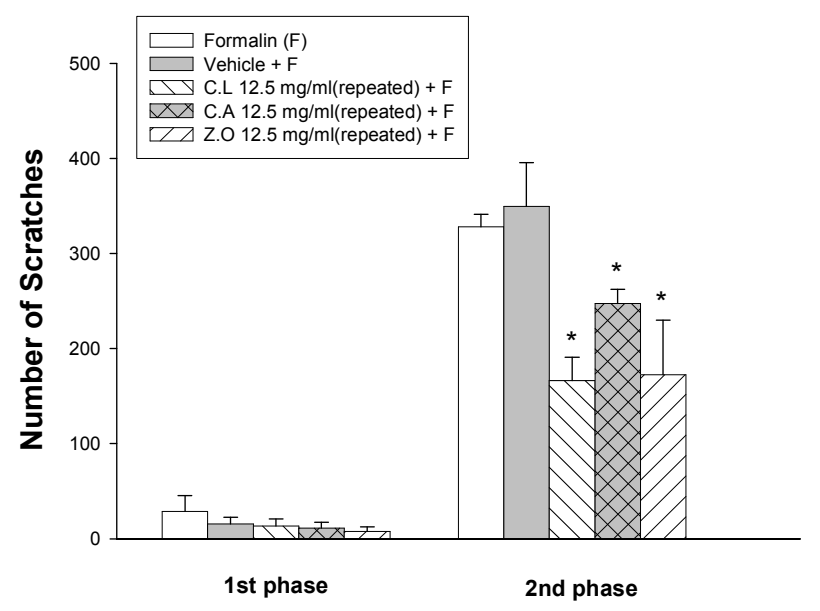

Fig. 9. Effects of repeated on nociceptive behavior at facial area. Following administration of repeated, the nociceptive responses were reduced in 2 nd phase in a dose-dependent manner. There were 6 animals in each group. ${ }^{*} P<0.05$, Formalin vs C.L, C.A Z.O $12.5 \mathrm{mg} / \mathrm{mL}+\mathrm{F}$.

C.L: Curcuma longa L., C.A: Curcuma aroma tica Salisb., Z.O: Zingiber officinale Rosc.

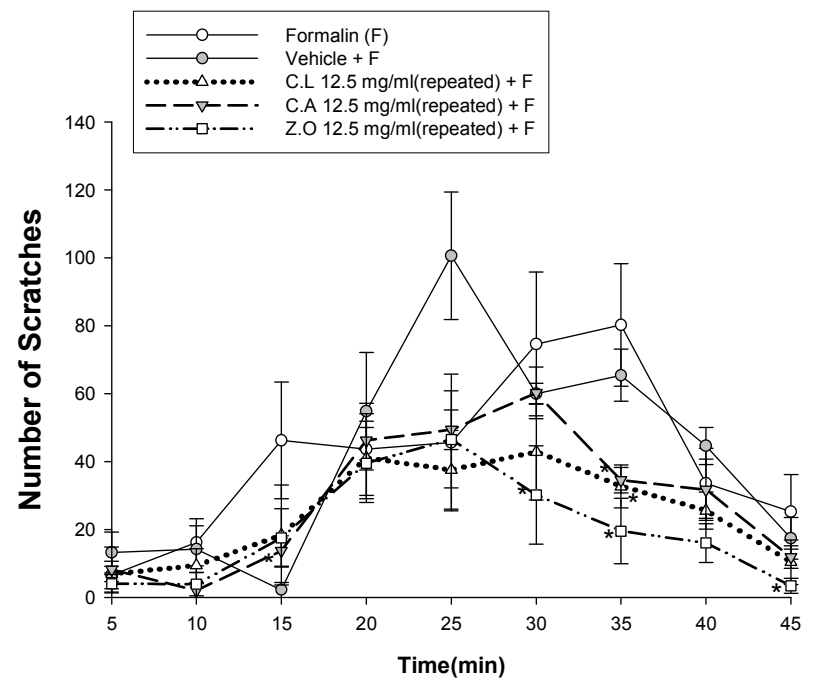

Fig. 10. Effects of repeated on nociceptive behavior at facial area. Following administration of repeated, the nociceptive responses were reduced in 2 nd phase in a dose-dependent manner. There were 6 animals in each group. ${ }^{*} P<0.05$, Formalin vs C.L, C.A, Z.O $12.5 \mathrm{mg} / \mathrm{mL}+\mathrm{F}$.

C.L: Curcuma longa L., C.A: Curcuma aroma tica Salisb., Z.O Zingiber officinale Rosc.

을 투여하여 유도한 안면부 염증성 통증에서 울금, 강황, 생강 반복 투여의 통증 행위 반응 조절 효과는 다음과 같 이 나타났다(Fig. 9). 안면부 부위의 1 차 통증 행위 반응의 
포르말린 군과 용매(CMC-Na) 군에서 각 $29.00 \pm 16.20$, $15.67 \pm 7.08$ 회로 나타났고, 울금, 강황, 생강 $12.5 \mathrm{mg} / \mathrm{mL}$ 반복 투여군에서의 통증 행위 1 차 반응의 결과에서는 각 $13.33 \pm 7.53$ 회, $11.33 \pm 6.17$ 회, $7.83 \pm 4.74$ 회로 나타나 대조군과 실험군 간의 큰 차이가 없었다. 통증 행위 2 차 반응의 결과에서는 포르말린군과 용매군은 각 $328.41 \pm$ $12.86,349.33 \pm 46.15$ 회로 통증 행위 반응이 높게 나타났 으며, $12.5 \mathrm{mg} / \mathrm{mL}$ 의 반복 투여군에서 울금, 강황, 생강은 각 $166.50 \pm 24.48$ 회, $247.33 \pm 14.98$ 회, $172.50 \pm 57.25$ 회 로 대조군과 비교하여 통증 행위 반응이 감소됨을 나타났 다. 반복 투여군을 비교하였을 때 가장 통증 행위 반응이 낮게 나타난 순서로는 울금, 생강, 강황이였으며 단회 투 여 시 보다 반복 투여 시에서 통증 행위 반응이 유의하게 감소됨을 확인하였다 $(P<0.05)$.

시간의 경과에 따른 통증 행위 반응의 변화는 다음과 같다(Fig. 10). 포르말린의 주입으로 유도된 통증 행위 반 응은 15 분 이후부터 증가하여 25 분에 가장 높게 나타났 으며 40 분까지 지속되다가 45 분에 감소하였다. $12.5 \mathrm{mg} /$ $\mathrm{mL}$ 의 생강과 식물들 반복 투여는 포르말린 주입 후 통증 행위 반응이 증가하는 20 분 부터 높았다가 30 분 이후로 감소됨을 나타났다.

\section{고 찰}

치과 질환 중 하나인 구강안면 통증은 삶의 질과 밀접 하게 연관되어 있으며, 여러 방면으로 환자에게 영향을 미친다. 안면부 통증이 일상생활이나 운동 활동 및 사회 적 활동에 미치는 영향은 이미 선행 연구에서도 밝혀졌 으며(Maulina et al., 2018), 이처럼 안면부 통증은 삶의 질과 밀접한 연관성이 있으므로 통증의 발생 예방과 치료가 필수적으로 요구된다. 그러나 안면부 염증성 통증 조절에 대한 연구는 현재 부족하다고 사료되어, 본 연구에서는 실험동물의 안면부에 포르말린을 주입한 염증성 통증 모 델을 적용하여 생강과 식물들에 속하는 울금, 강황, 생강 추출물의 통증 조절 효과를 확인하고자 하였다.

통증은 생체의 산화 및 노화에 주요 원인인 산화 스트 레스에 의해서도 통증이 유발될 수 있으며, 천연물 또는 식품 등에 함유되어 있는 다양한 항산화 물질의 작용에 의해 조절될 수 있다. 위암의 억제, 항산화 효과, 항균 활 성 등의 효능이 밝혀진 흰민들레의 선행 연구를 보면, RAW 264.7 세포를 LPS로 자극하였을 때 흰민들레 물 추 출물의 항염증 효과를 조사한 결과, NO 및 $\mathrm{IL}-1 \beta, \mathrm{IL}-6$ 의
생산을 억제하였으며, MAPKs 중 p38, JNK, ERK1/2의 인 산화와 $\mathrm{I} \kappa-\mathrm{B} \alpha$ 의 분해를 억제함을 확인하여 흰민들레가 항 염증 치료에 응용될 수 있다고 보고하였다(Kim et al., 2014). 또한 항암 및 진통 효과가 있는 감송향(Valerianaceae)의 항산화 및 항염증 효과를 알아본 실험에서는 감송향 $85 \%$ 메탄올 추출물은 in vitro에서 강한 항산화 활성이 확인되 었으며, LPS로 자극된 쥐의 복강 macrophage에서 염증성 매개 물질인 $\mathrm{NO}$ 의 생성이나 iNOS, COX-2 등의 발현을 억제하여 감송향이 동맥경화나 관절염 등의 산화적 스트 레스와 관련이 있는 만성 염증성 질환의 치료에 효과적으 로 사용될 수 있을 것으로 보고하였다(Baek et al., 2009). 이러한 연구 결과와 마찬가지로 본 연구에서 울금, 강황, 생강 추출물의 경구 투여는 포르말린으로 유도한 실험 모 델의 안면부 염증성 통증 행위 반응을 농도 의존적으로 감소됨을 확인하였다. 이와 같은 결과는 생강과 식물들의 생리 활성 성분이 염증성 통증의 조절에 관여한다는 것을 나타내며, 안면부 통증 조절에 효과적으로 적용할 수 있 을 것으로 생각된다.

구강과 관련된 통증인 신경병 변성 통증은 말초신경의 손상으로 인해 발생한다. 염증(inflammation)이란 macrophage나 mast cell 등의 백혈구에서 생성된 다양한 신호전 달물질이 관여하는 일련의 병리적인 과정으로서, 이 중 macrophage는 대표적인 염증 매개물인 NO (nitric oxide) 생성에 관여한다. $\mathrm{NO}$ 는 급성 및 만성 염증반응에서 $\mathrm{L}-$ arginine으로부터 iNOS (inducible nitric oxide synthase)에 의 해 과량 생성되며 염증반응을 촉진시키는 것으로 알려져 있다. iNOS는 LPS 자극에 의해 발현되는데 이는 과량의 $\mathrm{NO}$ 를 생성하게 되어 세포에 산화 스트레스를 주게 되며 (Baek et al., 2009; Kim et al., 2014), 이를 제거하는 생체 내 의 방어 시스템과의 균형이 무너지면 암을 비롯한 여러 질병의 발병에 관여하므로 산화 스트레스를 제거하는 항 산화 물질은 지질 과산화와 자유라디칼을 저해하는 등의 과정을 통해 여러 질환의 발병을 완화할 수 있는 후보 물 질이 될 수 있다고 하였다(Lee et al., 2013). 생강과 식물 중 울금, 강황의 성분에 포함된 curcumin은 선행 연구에 서 이미 항산화 물질로서의 효용이 밝혀져 있다. Curcumin 은 생강과 식물인 울금이나 강황에서 추출한 성분으로 항 산화 물질, 항암제, 항바이러스제로 많이 이용된다. 또한 산화에 의한 DNA 손상을 방지하고, free radical을 소거하 는 능력이 뛰어나다고 알려져 있다(Jeon and Kim, 2013). 흰 쥐에 고지방, 고콜레스테롤 식이와 함께 울금 분말을 농도 별로 공급하여 항산화계 및 산화적 손상에 미치는 
영향을 관찰한 연구에서 울금을 투여한 mice에서 간조직 의 세포막에 항산화력이 증가하고 있다고 보고하였으며, 울금은 조직 중의 과산화지질의 함량을 감소시키는 효과 가 있는 것으로 나타나 울금에 함유된 유기산 등 여러 항 산화계 물질이 조직의 산화를 억제하는 항산화계 기능을 확인하였다(Kim et al., 2013). 또한 급성 및 만성 염증 모델 에서의 강황 추출물의 항염증 효과를 연구한 실험에서는 급성 염증에 대한 효과를 알아보기 위하여 carrageenan에 의한 족부종 유발과 xylene에 의한 귀부종 유발을 일으킨 모델에 강황 추출물을 농도 별로 경구 투여하였을 때 염 증 억제율이 높은 것으로 나타났으며, 육아종 실험에서는 대조군과 비교하여 삼출물과 염증 육아종이 적게 발생된 것으로 나타났다. 따라서 강황을 경구 투여하였을 때 만 성 및 급성 염증에 대한 저해 활성이 있는 것으로 나타 나 항염증 소재로서 개발 가능성이 있음을 제시하였다 (Anandakumar et al., 2014). 이러한 선행 연구들로 비추어 볼 때 생강과 식물은 다양한 실험 모델에서 항산화 작용 및 항염증 작용을 확인하였다. 그러나 생강과 식물 추출 물이 구강안면부에 미치는 영향과 관련된 연구는 아직까 지 미미하다. 본 연구에서는 안면부 통증 조절 능력을 평 가하기 위하여 다양한 연구에서 항산화, 항염증 효과가 입증된 생강과 식물들을 실험 모델에 적용하였으며, 포르 말린으로 유도하여 증가한 통증 행위 반응은 경구로 주입 된 울금, 강황, 생강에 의해 농도 의존적으로 감소되었다. 이러한 결과는 포르말린으로 유발된 안면부 염증성 통증 발생에 생강과 식물들이 조절에 관여함을 알 수 있다. 또 한 각각의 약물을 단회 투여했을 시 보다 울금, 강황, 생 강 추출물의 저농도를 혼합한 혼합 투여군에서는 더 높 은 통증 조절 효과를 확인하였으며, 이러한 결과와 비교 하여 생강과 식물들 추출물의 저농도를 각각 반복 투여 한 군에서는 단회 투여 및 혼합 투여했을 시보다 반복 투 여군에서 통증이 더 감소되는 효과를 확인하였다. 이러한 결과로 울금, 강황, 생강의 통증 조절 효과는 안면부 염증 성 통증 조절에 필요한 천연 치료제 개발 후보 물질로 활용할 수 있을 것으로 시사한다.

\section{ACKNOWLEDGMENT}

None.

\section{CONFLICT OF INTEREST}

The authors have no conflict of interest regarding the publication of this article.

\section{REFERENCES}

Anandakumar S, Joseph JA, Bethapudi B, Agarwal A, Jung EB. Anti-inflammatory Effects of Turmeric (Curcuma longa L.) Extract on Acute and Chronic Inflammation Models. J Korean Soc Food Sci Nutr. 2014. 43: 612-617.

Bae SJ, Kim WS, Kang SK, Auh QS, Hong JP, Chun YH. Sex Differences in the Pain Control by the Peripheral Opioid. Korean Journal of Oral Medicine. 2013. 38: 339-356.

Baek S, Choi JH, Ko SH. Antioxidant and Anti-inflammatory Effect of Nardostachys Chinensis in IFN- $\gamma /$ LPS-stimulated Peritoneal Macrophage. Korean J Oriental Physiology \& Pathology. 2009. 23: 853-859.

Choi SH, Kim KS, Kim ME, Lee DJ, Jin SB. Treatment Outcome and Prognosis of the Outpatients with Orofacial Pain. Korean Journal of Oral Medicine. 2006. 31: 155-165.

Guon TE, Chung HS. Effect of Zingiber officinale Roscoe Extract on Antioxidant and Apoptosis in A2058 Human Melanoma Cells. J East Asian Soc Diet Life. 2016. 26: 207-214.

Hwang HS, Park GD. Research Paper: A Comparative Study of Anti-oxidant Effect and Cell Proliferation Effect based on Extraction Method of Natural Substances. Journal of Korean Beauty Society. 2015. 21: 729-736.

Jeon YJ, Kim DY. The Antioxidant Effect of Curcumin on Miniature Pig Sperm Cryopreservation. Journal of Chitin and Chitosan. 2013. 18: 190-197.

Kim EJ, Choi JY, Yu MR, Kim MY, Lee SH, Lee BH. Total Polyphenols, Total Flavonoid Contents, and Antioxidant Activity of Korean Natural and Medicinal Plants. Korean Journal of Food Science and Technology. 2012. 44: 337-342.

Kim EJ, Song BN, Jeong DS, Kim SY, Cho YS, Park SY. Antioxidative and Anti-inflammatory Activities of Fermented Turmeric (Curcuma longa L.) by Rhizopus oryzae. Journal of Life Science. 2017. 27: 1315-1323.

Kim HJ, Lee JW, Kim YD. Antimicrobial Activity and Antioxidant Effect of Curcuma longa, Curcuma aromatica and Curcuma zedoaria. Korean J Food Preserv. 2011. 18: 219-225.

Kim JJ, Ahn SI, Lee JS, Yun SM, Lee MY, Youn HS. Suppression of the Expression of Cyclooxygenase-2 Induced by Toll-like Receptor 2, 3, and 4 Agonists by 6-Shogaol. Korean J Food Sci Technol. 2008. 40: 332-336.

Kim MJ, Bae GS, Choi SB, et al. The anti-inflammatory effect of Taraxacum coreanum on lipopolysaccharide induced inflam- 
matory response on RAW 264.7 cells. Kor J Herbology. 2014. 29: $21-26$

Kim MS, Chun SS, Choi JH. Effects of Turmeric (Curcuma longa $L$.) on Antioxidative Systems and Oxidative Damage in Rats Fed a High Fat and Cholesterol Diet. J Korean Soc Food Sci Nutr. 2013. 42: 570-576.

Kim SH, Lee HS. Acute Oral Toxicity Study of Ethanol Extract of Curcuma longa L. in Mice. Journal of Life Science. 2014. 24: 1132-1136.

Lee SE, Choi JH, Lee JH, et al. Screening of Useful Plants with Anti-inflammatory and Antioxidant Activity. Korean J Plant Res. 2013. 26: 441-449.

Lee SY, Park SH, Kang JY, et al. The establishment of natural materials library for the oral disease. Oral Biology Research. 2011. 35: 47-54.

Lee YJ, Kim EO, Choi SW. Isolation and Identification of Antioxidant Polyphenolic Compounds in Mulberry (Morus alba L.) Seeds. Journal of the Korean Society of Food Science and Nutrition. 2011. 40: 517-524.

Maulina T, Yubiliana G, Rikmasari R. The Effectiveness of Orofacial Pain Therapy in Indonesia: A Cross-Sectional Study. Pain Research and Treatment. 2018.

Moritani NH, Hara ES, Kubota S. New Functions of Classical Compounds against Orofacial Inflammatory Lesions. Medicines.
2018. 5: 118

Park MK, Lee JH, Yang GY, et al. Peripheral administration of NR2 antagonists attenuates orofacial formalin-induced nociceptive behavior in rats. Prog Neuropsychopharmacol Biol Psychiatry. 2011. 35: 982-986.

Song YJ, Ha CW. Review Articles : The Use of COX-2 Selective Nonsteroidal Anti-inflammatory Drugs for the Treatment of Osteoarthritis. Knee Surgery \& Related Research. 2009. 21: 93-101.

Yoon JH, Ryu BH, Kim JS, Yoon SH. Effects of Curmuma longa $L$. on Some Kinds of Cancer Cells Korean J. Orient Int Med. 2006. 27: 429-443.

Yoon YI, Hwang JS, Kim MA, et al. Inhibition of Inflammation by Popillia flavosellata Ethanol Extract in LPS-induced RAW264.7 Macrophages. Journal of Life Science. 2015. 25: 993-999.

https://doi.org/10.15616/BSL.2019.25.3.247

Cite this article as: Kim HJ, Choi JH, Kim HJ, Yoon HS, Lee MK. Modulation Effects on Acute Orofacial Inflammatory Pain in Rats by Curcuma longa L., Curcuma aromatica Salisb., Zingiber officinale Rosc. Extracts. Biomedical Science Letters. 2019. 25: 247-255. 